\title{
Experimental Investigation into Internal Erosion Potential for Granular Filters
}

\author{
Jahanzaib Israr ${ }^{1}$, Buddhima Indraratna ${ }^{2}$, Cholachat Rujikiatkamjorn ${ }^{3}$ \\ School of Civil, Mining and Environmental Engineering, University of Wollongong, NSW, Wollongong, Australia \\ E-mails: ${ }^{1} j i 797 @ u o w m a i l . e d u . a u$ (correspondingauthor); ${ }^{2}$ indra@uow.edu.au; ${ }^{3}$ cholacha@uow.edu.au
}

\begin{abstract}
Internal erosion is a phenomenon whereby the filtrates under the influence of significant seepage forces accompany the finer fraction from potential internally unstable filters (e.g. broadly- and gap-graded soil), occasionally rendering them ineffective. The filter assessment for internal erosion or instability potential is emphasized through particle size distribution based geometrical criteria ignoring the effect of compaction. In this study, the results of hydraulic gradient controlled internal erosion tests conducted over a wide range of compacted sand-gravel mixtures were used to analyse some of the available geometrical criteria, which interestingly showed partial success in assessing the filter's internal erosion potential. It was revealed that the occurrence of internal erosion is a combined function of particle size distribution and the relative density of soils that had been ignored in many of the existing criteria. A comparison between the assessments obtained from some of the particle size based criteria and that from a constriction size based technique was reported for a large body of published data. It was observed that the latter criterion, which incorporates the effects of both particle size distribution and relative density of soils in tandem, could assess the reported test results with higher accuracy.
\end{abstract}

Keywords: granular filters, internal erosion, hydraulic gradient, relative density, constriction, particle size.

Conference topic: Soil and rock investigation, geoenvironmental engineering, and erosion control.

\section{Introduction}

Internal instability is a phenomenon whereby the erodible finer fraction from a non-uniform granular soil is eroded by the seepage forces, resulting into an increasingly porous medium. Protective filters in earth dams and railway substructures are selected on the basis of contradictory requirements of good permeability and adequate retention characteristics. However, selection of a potential internally unstable soil as a filter may not fulfil these requirements. Occurrence of internal erosion causes changes in grain size distribution (GSD) of filter that may consequently become too porous to retain the protected base soil (USACE 1953).

In literature, the phenomenon of internal instability is recalled with various terminologies, e.g. piping (Terzaghi 1939), internal and external piping (Lane 1934), segregation piping (Skempton, Brogan 1994), tunnelling or jugging (Jones 1981), suffusion (Kezdi 1979; Israr et al. 2016a, 2016b), Suffosion (Kenney, Lau 1985) and excessive washout (Indraratna et al. 2015) etc. Failures of up to $46 \%$ of all water impounding structures could be attributed to the problem of internal instability (Richards, Reddy 2007).

In general, the non-uniform (bi-modal) soils suffer from this problem, exhibiting excessive washout of their finer fractions due to seepage flow, e.g. broadly- and gap-graded soils (Indraratna et al. 2012). In such soils, the internal instability reportedly occurs at hydraulic gradients significantly smaller than Terzaghi's critical hydraulic gradient for quick sand condition (e.g. $0.2-$ $0.5 \times \mathrm{i}_{\text {cr }}$ ). In practice, the potential for internal instability is considered a function of soil gradation (uniformity coefficient $\mathrm{C}_{\mathrm{u}}$, percentage of fines, shape and slope of GSD curve etc.), based on which various geometrical criteria have been established so far.

For instance, Kezdi (1979) and Sherard (1979) applied Terzaghi's filter retention criterion on a split soil gradation curve to assess potential for instability. They proposed that soil gradations with $\mathrm{D}^{\mathrm{c}}{ }_{15} / \mathrm{d}_{85}^{\mathrm{f}}>4$ and 5 , respectively, would suffer from instability $\left(\mathrm{D}^{\mathrm{c}}{ }_{15}\right.$ and $\mathrm{d}_{85}^{\mathrm{f}}$ particle sizes corresponding to $15^{\text {th }}$ and $85^{\text {th }}$ percentile finer for coarse and finer fraction, respectively). Kenney and Lau (1985) proposed that a particle d can erode through the constrictions (windows joining two adjacent pores) formed by particles sizing $4 \mathrm{~d}$ and the absence of intermediate particles indicated by $(\mathrm{H} / \mathrm{F})_{\min }<1$.

Locke et al. (2001) showed that the coasre primary fabric constitutes a variety of constriction sizes that depends on GSD and level of compaction $\left(\mathrm{R}_{\mathrm{d}}\right)$ of soil. For instance, the largest constriction size is obtained by four soil particles in contact in loosest state of compaction $\left(R_{d}=0 \%\right)$, while the smallest constriction sizes are obtained with at least three soil grains in contact at the densest state of compaction $\left(\mathrm{R}_{\mathrm{d}}=100 \%\right)$. The intermediate constriction sizes could be evaluated based on stochastic theory as a function of GSD and $R_{d}$.

This current study aimed to evaluate the roles of GSD, level of compaction and hydraulic gradients in controlling the internal erosion potential of soils. Results are reported from a series of hydraulic gradient controlled piping tests on six sand-gravel mixtures with a variation of $\mathrm{C}_{\mathrm{u}}(=1-40)$ and compacted at different $\mathrm{R}_{\mathrm{d}}(=5-95 \%)$. Experimentally observed critical hy- 
draulic gradients are compared with those obtained from classical piping theory of Terzaghi (1922) and results are presented. Consequently, some of the well-accepted GSD and constriction size distribution (CSD) based criteria were adopted for geometrical assessment of current test samples plus a large body of additional specific data adopted from literature and their comparison is reported.

\section{Experimental program}

\section{Test material, setup and procedure}

Figure 1 shows GSD curves for current test specimens (soils 1-6), for which 20 hydraulic tests were conducted by varying their relative densities. For instance, soils 1 , 2,3 and 6 were compacted at $R_{d}=5,50$ and $95 \%$, soil 4 was compacted at $\mathrm{R}_{\mathrm{d}}=5,50,70$ and $95 \%$, and soil 5 at $\mathrm{R}_{\mathrm{d}}=5,30,60$, and $95 \%$. The geometrical assessments from some of the well-accepted GSD based criteria for tested soils (Kezdi 1979; Sherard 1979; Kenney, Lau 1985; Wan, Fell 2008; Indraratna et al. 2015) and a summary of laboratory test results are presented in Table 1. The moist soil (at wet of optimum) was mixed beforehand and layered compaction was performed to achieve target $R_{d}$.

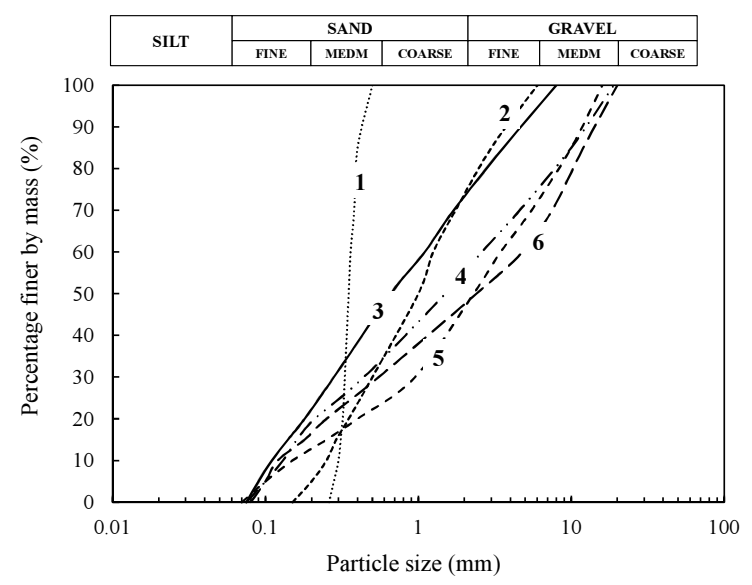

Fig. 1. Grain size distribution curves for test samples

Table 1. General soil properties for test gradations

\begin{tabular}{|c|c|c|c|c|c|c|c|c|c|c|c|c|}
\hline \multirow{2}{*}{$\begin{array}{l}\text { Test } \\
\text { No. }\end{array}$} & \multirow{2}{*}{$\begin{array}{l}\text { Sample } \\
\text { ID }\end{array}$} & \multicolumn{2}{|c|}{ Estimated } & \multicolumn{4}{|c|}{ Observed } & \multicolumn{5}{|c|}{ Geometrical assessment results } \\
\hline & & $\mathrm{R}_{\mathrm{d}}(\%)$ & $i_{c t}$ & $\begin{array}{c}\text { Pre } \\
\text {-test } C_{u}\end{array}$ & $\begin{array}{c}\text { Post } \\
\text {-test } \mathrm{C}_{\mathrm{u}}\end{array}$ & $i_{c r}$ & $\begin{array}{l}\text { Internal } \\
\text { stability }\end{array}$ & $\begin{array}{l}\text { Kezdi } \\
(1979)\end{array}$ & $\begin{array}{c}\text { Sherard } \\
(1979)\end{array}$ & $\begin{array}{l}\text { Kenney and } \\
\text { Lau (1985) }\end{array}$ & $\begin{array}{c}\text { Wan and Fel } \\
(2008)\end{array}$ & $\begin{array}{l}\text { Indraratna } \\
\text { et al. }(2015)\end{array}$ \\
\hline 1 & 1 & 6.57 & 0.97 & 1.2 & 1.2 & 1.07 & $\sqrt{ }$ & $\sqrt{ }$ & $\sqrt{ }$ & $\sqrt{ }$ & $\sqrt{ }$ & $\sqrt{ }$ \\
\hline 2 & 1 & 52.3 & 1.07 & 1.2 & 1.2 & 1.18 & $\sqrt{ }$ & $\sqrt{ }$ & $\sqrt{ }$ & $\sqrt{ }$ & $\sqrt{ }$ & $\sqrt{ }$ \\
\hline 3 & 1 & 94.3 & 1.18 & 1.2 & 1.2 & 1.29 & $\sqrt{ }$ & $\sqrt{ }$ & $\sqrt{ }$ & $\sqrt{ }$ & $\sqrt{ }$ & $\sqrt{ }$ \\
\hline 4 & 2 & 6.94 & 0.94 & 5 & 5 & 1.0 & $\sqrt{ }$ & $\sqrt{ }$ & $\sqrt{ }$ & $\sqrt{ }$ & $\sqrt{ }$ & $\sqrt{ }$ \\
\hline 5 & 2 & 51.94 & 1.03 & 5 & 5 & 1.05 & $\sqrt{ }$ & $\sqrt{ }$ & $\sqrt{ }$ & $\sqrt{ }$ & $\sqrt{ }$ & $\sqrt{ }$ \\
\hline 6 & 2 & 92.5 & 1.13 & 5 & 5 & 1.10 & $\sqrt{ }$ & $\sqrt{ }$ & $\sqrt{ }$ & $\sqrt{ }$ & $\sqrt{ }$ & $\sqrt{ }$ \\
\hline 7 & 3 & 5.5 & 0.93 & 10 & 10 & 0.9 & $\sqrt{ }$ & $\sqrt{ }$ & $\sqrt{ }$ & $\sqrt{ }$ & $\sqrt{ }$ & $\sqrt{ }$ \\
\hline 8 & 3 & 47.2 & 1.01 & 10 & 10 & 1.0 & $\sqrt{ }$ & $\sqrt{ }$ & $\sqrt{ }$ & $\sqrt{ }$ & $\sqrt{ }$ & $\sqrt{ }$ \\
\hline 9 & 3 & 92.77 & 1.12 & 10 & 10 & 1.05 & $\sqrt{ }$ & $\sqrt{ }$ & $\sqrt{ }$ & $\sqrt{ }$ & $\sqrt{ }$ & $\sqrt{ }$ \\
\hline 10 & 4 & 6.1 & 0.92 & 20 & 23.7 & 0.45 & $\sqrt{ }$ & $\sqrt{\mathrm{U}}$ & $\sqrt{\mathrm{U}}$ & $\sqrt{\mathrm{U}}$ & $\sqrt{\mathrm{U}}$ & $X$ \\
\hline 11 & 4 & 51.38 & 1.02 & 20 & 22.2 & 0.56 & $X$ & $\sqrt{\mathrm{U}}$ & $\sqrt{\mathrm{U}}$ & $\sqrt{\mathrm{U}}$ & $\sqrt{\mathrm{U}}$ & $\mathrm{X}$ \\
\hline 12 & 4 & 71.1 & 1.07 & 20 & 20 & 0.90 & $\sqrt{ }$ & $\sqrt{ }$ & $\sqrt{ }$ & $\sqrt{ }$ & $\sqrt{ }$ & $\sqrt{ }$ \\
\hline 13 & 4 & 95.55 & 1.14 & 20 & 20 & 0.98 & $\sqrt{ }$ & $\sqrt{ }$ & $\sqrt{ }$ & $\sqrt{ }$ & $\sqrt{ }$ & $\sqrt{ }$ \\
\hline 14 & 5 & 7.35 & 0.93 & 23 & 18.2 & 0.62 & $X$ & $X$ & $X$ & $\sqrt{\mathrm{U}}$ & $\sqrt{\mathrm{U}}$ & $\mathrm{X}$ \\
\hline 15 & 5 & 32.05 & 0.98 & 23 & 23 & 0.79 & $\sqrt{ }$ & $\mathrm{X}^{\mathrm{C}}$ & $\mathrm{X}^{\mathrm{C}}$ & $\sqrt{ }$ & $\sqrt{ }$ & $\sqrt{ }$ \\
\hline 16 & 5 & 63.2 & 1.05 & 23 & 23 & 0.94 & $\sqrt{ }$ & $\mathrm{X}^{\mathrm{C}}$ & $\mathrm{X}^{\mathrm{C}}$ & $\sqrt{ }$ & $\sqrt{ }$ & $\sqrt{ }$ \\
\hline 17 & 5 & 93.5 & 1.13 & 23 & 23 & 1.03 & $\sqrt{ }$ & $\mathrm{X}^{\mathrm{C}}$ & $\mathrm{X}^{\mathrm{C}}$ & $\sqrt{ }$ & $\sqrt{ }$ & $\sqrt{ }$ \\
\hline 18 & 6 & 6.3 & 0.92 & 40 & 10 & 0.28 & $X$ & $X$ & $\sqrt{\mathrm{U}}$ & $X$ & $\sqrt{\mathrm{U}}$ & $X$ \\
\hline 19 & 6 & 48 & 1.02 & 40 & 11.2 & 0.31 & $X$ & $X$ & $\sqrt{\mathrm{U}}$ & $X$ & $\sqrt{\mathrm{U}}$ & $\mathrm{X}$ \\
\hline 20 & 6 & 92.5 & 1.14 & 40 & 12.5 & 0.37 & $X$ & $X$ & $\sqrt{\mathrm{U}}$ & $X$ & $\sqrt{\mathrm{U}}$ & $\mathrm{X}$ \\
\hline
\end{tabular}

Note: $\sqrt{ }=$ internally stable and $\mathrm{X}=$ internally unstable. Superscripts, $\mathrm{C}$ and $\mathrm{U}$ represent conservative and unsafe predictions, respectively. 
Additional details on sample preparation including compaction, saturation and assessments of uniformity of tested samples with respect to size distribution and compaction can be obtained from Indraratna et al. (2015). The test apparatus was consisted of a $150 \mathrm{~mm}$ diameter smooth-wall perspex cell that could accommodate $200 \mathrm{~mm}$ long test samples (Fig. 2). The cell dimensions were sufficient to avoid potential boundary effects $\left(d_{c} / D_{100}>9\right.$, where $d_{c}=$ cell diameter and $D_{100}=$ largest particle size) e.g. effects of cell wall friction and preferential flow on soil erosion (Zou et al. 2013).

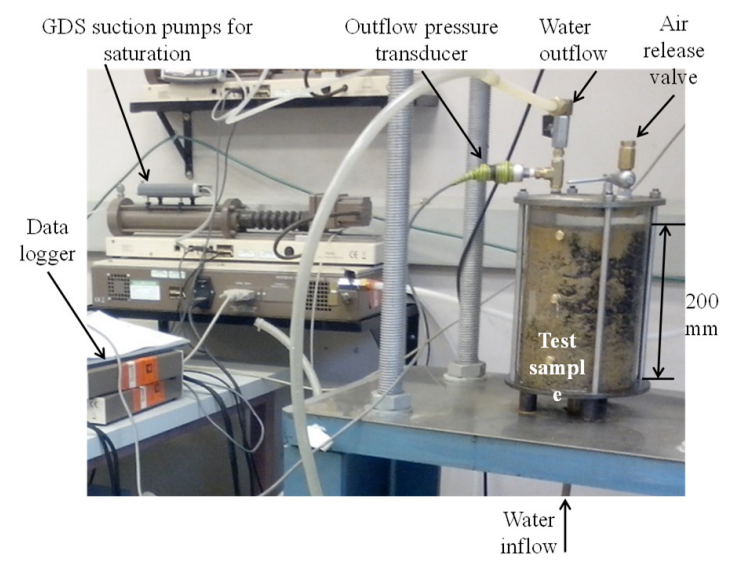

Fig. 2. Illustration of current test setup

During tests, the saturated samples were subjected to the upward flow of water at pre-requisite hydraulic pressure levels (hence the hydraulic gradients, $i$ ). The applied $i$-values were increased at a controlled rate, e.g. the increment rates of $\Delta i=0.05$ and 0.025 per 30 minutes were adopted for potential internally stable samples 1-3 and unstable samples 4-6, respectively.

\section{Results and discussion}

Figure 3 presents the hydraulic response and effluent turbidity variations for selected test samples including an internally stable sample-3 (Fig. 3a), a marginal sample-4 (Fig. 3b) and an internally unstable sample 6 (Fig. 3c) compacted at varying relative densities between 5 and $95 \%$. The onset of seepage induced instability could be characterized by a sudden increase in volumetric flow rate. It was indicated by the steepening flow curve with effluent turbidity significantly greater than $60 \mathrm{NTU}$ and the corresponding $i$-values were measured as $i_{c r}$ (after Skempton, Brogan 1994). At this onset, the development of heave failure in an internally stable sample (1-3), excessive washout in an unstable sample (6) and composite failure response in marginal samples (4-5) could be visually observed.

Figure 4a shows the relationships between relative density and stress reduction factor $\alpha\left(=i_{c r} / i_{c t}\right)$, i.e. ratio between observed critical hydraulic gradient $i_{c r}$ and Terzaghi's critical hydraulic gradient for soil piping $i_{c t}$ $\left(=\mathrm{G}_{\mathrm{s}}-1 / 1+\mathrm{e}\right)$. For current results, four distinct zones could be identified, whereby highly stable samples 1 to 3 and unstable sample 6 were plotted in extreme zones and their internal stability potential was observed to be independent of relative density.

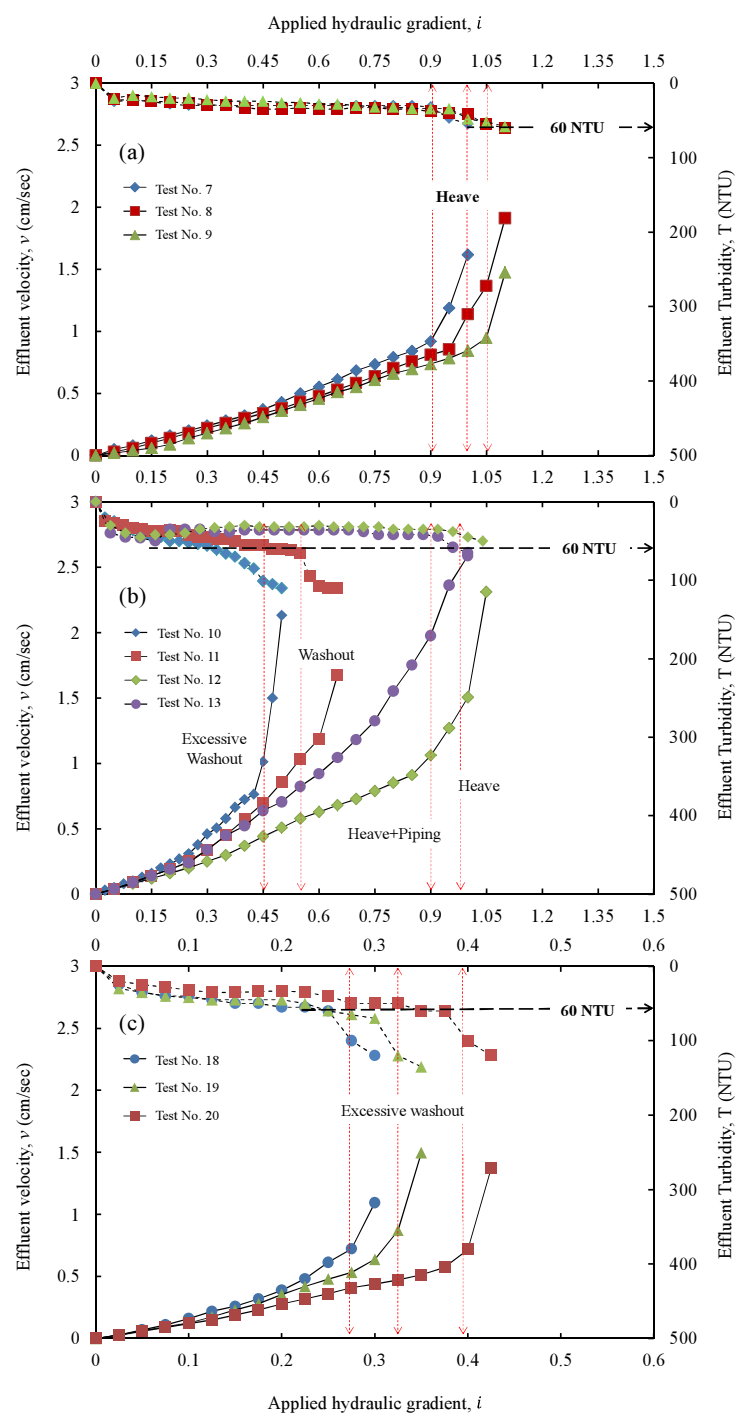

Fig. 3. Hydraulic response of selected test samples, i.e. internally (a) stable (b) marginal and (c) unstable

Samples 4 and 5 were plotted in the middle zones (marginally stable and marginally unstable) and exhibited variable response when their relative densities were increased from $5 \%$ to $95 \%$. It was revealed that the internal stability of these gradations increased significantly with the increase in level of compaction. For instance, both samples 4 and 5 initially experienced excessive washout at very low $i_{c r}$-values $(=0.45$ and 0.65 , respectively) when compacted at $R_{d}=5 \%$. However, the magnitudes of $i_{c r}$ increased almost two-fold at $\mathrm{R}_{\mathrm{d}}=95 \%$, and sample 4 and 5 exhibited composite heave-piping and pure heave failure, respectively.

As shown in Figure 3b, sample 4 exhibited remarkable improvements in the magnitude of $i_{c r}$ from 
0.48 at $\mathrm{R}_{\mathrm{d}}=5 \%$ to 0.82 at $\mathrm{R}_{\mathrm{d}}=72 \%$ that improved further to 0.91 at $R_{d}=95 \%$. Notably, the type of seepage induced failure at the onset of internal instability dramatically changed from excessive washout at $R_{d}=5 \%$ to composite heave-piping failure at $R_{d}=95 \%$. Generally, an increase in compaction level resulted in the reduction of percentile eroded fines that could subsequently transform some of the marginal samples into internally stable, e.g. samples 4 and 5 (Fig. 4b).
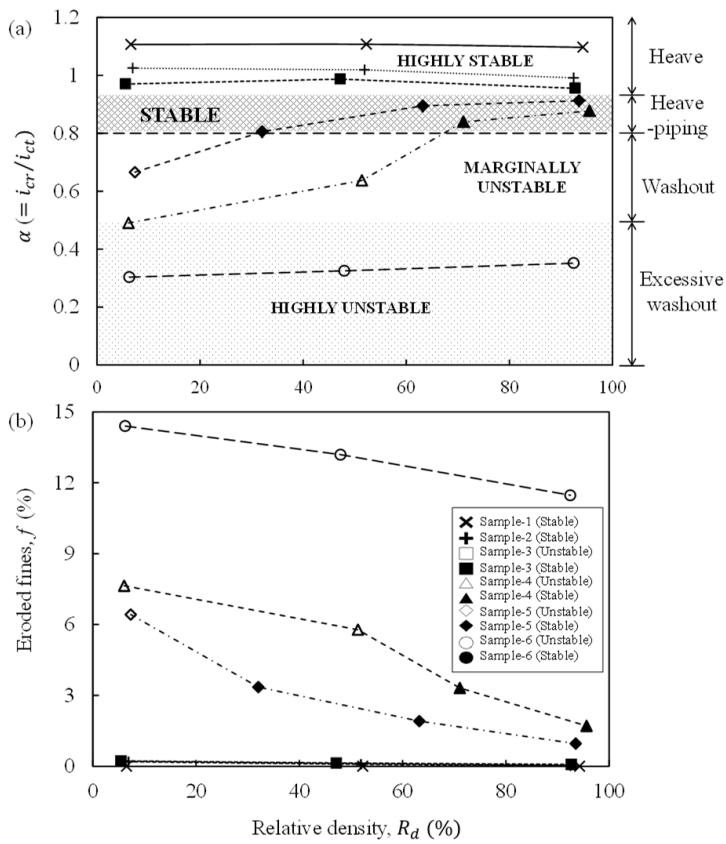

Fig. 4. Effect of compaction on (a) critical hydraulic gradient and (b) percentile eroded fraction for tested samples

A comparison between the results of pre- and posttest sieve analysis of soil recovered from the middle layers revealed that the samples at $R_{d}>72 \%$ experienced no erosion of their finer fractions and could be considered stable based on the criterion of Kenney and Lau (1985). Figure 5 shows the initiation, progression and development of seepage induced failure in a marginally stable sample-4 (Test. No. 12).

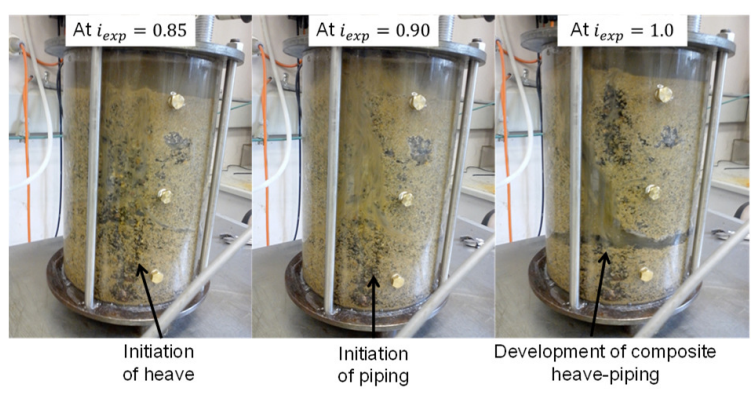

Fig. 5. Development of internal instability in sample-4 at Relative density $=72 \%$ (Test No. 12)

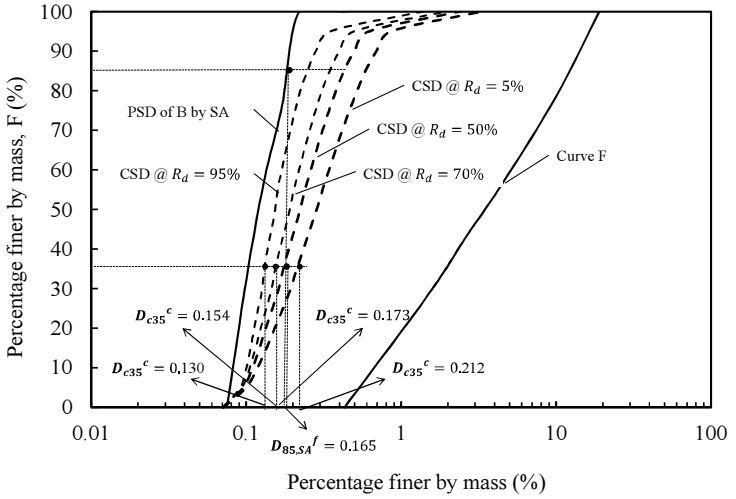

Fig. 6. Effect of level of compaction on constriction size distribution of coarser fraction of sample- 4

In Figure 6, sample-4 was divided into coarser and finer fractions by using the method of Indraratna et al. (2015) and CSD-curves were plotted at $R_{d}=5-95 \%$ and GSD by surface area was plotted for the finer fraction. The analysis revealed that the $\mathrm{d}_{85}^{\mathrm{f}}$, SA for finer fraction was smaller than the $\mathrm{D}^{\mathrm{c}}{ }_{35 \mathrm{c}}$ for coarser fraction for $\mathrm{R}_{\mathrm{d}}<70 \%$, however, further increase in compaction beyond $R_{d}=70 \%$ significantly reduced $D_{35 c}^{c}$ that could consequently retain $\mathrm{d}_{85, \text { SA }}^{\mathrm{f}}$ (Fig. 6).

\section{Assessments of internal erosion potential}

\section{Grain size distribution based criteria}

Table 1 shows the results of internal stability assessments obtained from the GSD based criteria of Kezdi (1979), Sherard (1979), Kenney and Lau (1985), and Wan and Fell (2008) for the current test results. The approaches of Kezdi, Sherard, and Wan and Fell yielded 5,8 , and 6 incorrect predictions, respectively. The criterion of Kenney and Lau showed a higher degree of accuracy with only 3 incorrect assessments. Figure 7 shows the results of selected geometrical assessments

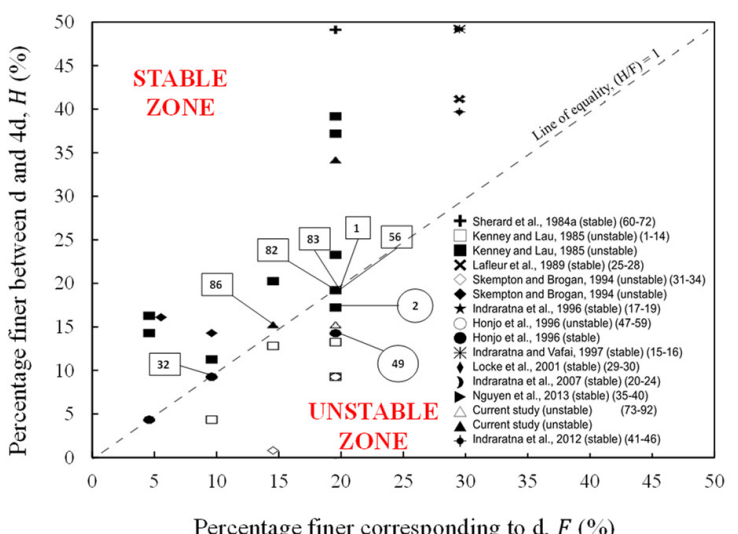

Fig. 7. Geometrical assessments of internal instability potential by the grain size distribution based criterion of Kenney and Lau (1985) (Source: Sherard et al. 1984; Kenney, Lau 1985; Lafleur et al. 1989; Skempton, Brogan 1994; Indraratna et al. 1996, 2007, 2012; Honjo et al. 1996; Indraratna, Vafai

1997; Locke et al. 2001; Nguyen et al. 2013 and current study) 
by Kenney and Lau (1985) criterion for a larger dataset of 92 test results adopted from published literature (after Indraratna et al. 2015) plus current results. This time, the method of Kenney and Lau resulted into 8 incorrect assessments including 6 unsafe (numbers in square box) and only 2 safe predictions (numbers in circles).

\section{Constriction size distribution based criterion}

Figure 8 presents the results of geometrical assessments obtained from combined particle and constriction size distribution (CP-CSD) method of Indraratna et al. (2015) for the same dataset of 92 results and only one incorrect assessment was obtained. Notably, this test result corresponds to the stability boundary of Kenney and Lau's (1985) criterion and the currently tested sample-4, which was experimentally observed as internally stable in the absence of vibrations at $R_{d}>70 \%$.

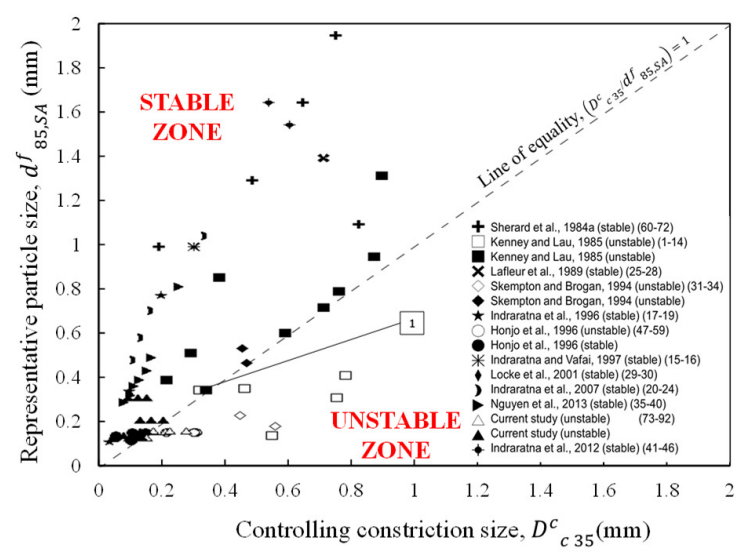

Fig. 8. Geometrical assessments of internal instability by the constriction size distribution based criterion of Indraratna et al. (2015)

The probable explanation for this discrepancy could be that the above marginal specimen is only partially stable at higher compaction levels with no vibrations imparted during the hydraulic test (Kenney, Lau 1985). For instance, the vibration induces perturbations to the specimen that disturbs its constriction network. Consequently, the $\mathrm{D}_{35 \mathrm{c}}^{\mathrm{c}}$ of the filter fluctuates rapidly and the finer fraction inside the pore spaces can be easily washed out by the seepage forces.

Not surprisingly at higher compaction levels $\left(\mathrm{R}_{\mathrm{d}}>\right.$ $70 \%$ ), relatively tighter constrictionn networks are obtained. Nevertheless, fully compacted filters exhibit lesser disturbance due to vibrations and cyclic loading up to $5 \mathrm{~Hz}$ (Israr et al. 2016a, 2016b). Therefore, the effects of vibrations can be minimised by compacting the soil specimens at higher $R_{d}(\geq 90 \%)$ and hence their internal stability is improved.

In this study, results are reported from a series of hydraulic gradient controlled piping tests conducted over a selected range of granular soils at various compaction levels from $R_{d}=5$ to $95 \%$. Analysis of results revealed that the internal erosion potential is a combined function of GSD and $\mathrm{R}_{\mathrm{d}}$ of soils (hence, the CSD) that had been ignored in many of the established criteria. The risk of occurrence of internal erosion escalates with the use of broadly-graded soils, whereas it is less critical in relatively uniform soils $\left(\mathrm{C}_{\mathrm{u}}<10\right)$.

Nevertheless, soils with higher uniformity coefficients $\left(10<\mathrm{C}_{\mathrm{u}}<23\right)$ compacted at higher $\mathrm{R}_{\mathrm{d}}$ could show enhanced degree of stability during current tests (with no vibrations). However, the current sample 6 with $\mathrm{C}_{\mathrm{u}}=40$ showed less sensitivity to the level of compaction. In essence, the compaction has more significance in reducing the internal erosion potential of soils with $\mathrm{C}_{\mathrm{u}} \leq 23$ provided no vibrations are imparted during hydraulic tests. An alternative approach for minimising the risk of internal erosion can be the use of uniformly-graded soils $\left(\mathrm{C}_{\mathrm{u}}<10\right)$.

\section{Practical implications}

The hydraulic test results revealed that the uniform soils $\left(\mathrm{C}_{\mathrm{u}} \leq 10\right)$ show higher resilience against internal erosion, regardless of level of comapction. Given that the availability of uniform soils for earth dams and railway substructures can be practically infeasible, an alternate approach can be placing the available soil at higher $\mathrm{R}_{\mathrm{d}}$.

Alternatively, assessing the potential for internal erosion and suffusion can be beneficial for selecting an appropriate protective filter. The existing GSD based criteria have been proven to be less accurate and often insecure in correctly quantifying the erosion potential. Not surprisingly, the CSD based approach of Indraratna et al. (2015) that is sensitive to both GSD and $\mathrm{R}_{\mathrm{d}}$ of soils showed higher distinction in correctly assessing a large experimental dataset. Given the $99 \%$ accuracy in correctly determining the internal erosion potential, this approach should be more appealing to the practitioners.

\section{Conclusions}

The following conclusions could be drawn from this study:

The potential for internal erosion is a characteristic associated with the shape of GSD curve and $R_{d}$ of soil. It is generally exhibited by the non-uniform soils with higher uniformity coefficients $(\mathrm{Cu}>10)$. The amount and rate of erosion are indirectly related with the level of compaction $\left(\mathrm{R}_{\mathrm{d}}\right)$ of soils. Higher erosion is observed at lower $R_{d}$, whereas the erosion decreases with the increase in $\mathrm{Rd}$. For instance, samples 4, 5 and 6 exhibited up to $6 \%, 7 \%$ and $2.5 \%$ reduction in eroded fines, respectively, when their $R_{d}$ increased from $5 \%$ to $95 \%$.

Internally stable soils exhibited heave and composite heave-piping failure at hydraulic gradients approximately equal to those determined from piping theory of Terzaghi (1922). No significant changes were observed in the pre- and post-test $\mathrm{C}_{\mathrm{u}}$ and GSD curves of stable soils due to the occurrence of heave and heave-piping. In contrast, internally unstable specimens showed excessive internal erosion at relatively smaller hydraulic gradients that resulted in changes in their GSD and $\mathrm{C}_{\mathrm{u}}$. 
To re-examine the current test results, a number of well-accepted grain size distribution (GSD) and constriction size distribution (CSD) based geometrical criteria were adopted and their assessment results were reported. Notably, the GSD based criteria ignoring the effect of compaction showed partial success in delineating the exact potential for internal erosion, while it was observed that the CSD based criterion, which incorporates both GSD and $R_{d}$, could more accurately assess the reported test results (i.e. success $\geq 99 \%$ ).

\section{Acknowledgements}

Financial supports received by the second author from UoW Australia and UET Lahore in the form of IPTA and FDP scholarships, respectively, are gratefully acknowledged. Special thanks to the technical staff of High-bay laboratory of UoW.

\section{Disclosure statement}

The authors hereby testify that they have no financial interests from other parties.

\section{References}

Honjo, Y.; Haque, M. A.; Tsai, K. A. 1996. Self-filtration behaviour of broadly and gap-graded cohesionless soils, in J. Lafleur, A. Rollin (Eds.). Geofilters'96. Montreal: Bitech Publications, 227-236.

Indraratna, B.; Vafai, F. 1997. Analytical model for particle migration within base soil-filter system, Journal of Geotechnical and Geoenvironmental Engineering 123(2): 100-109.

http://dx.doi.org/10.1061/(ASCE)1090-0241(1997)123:2(100)

Indraratna, B.; Israr, J.; Rujikiatkamjorn, C. 2015. Geometrical method for evaluating the internal instability of granular filters based on constriction size distribution, Journal of Geotechnical and Geoenvironmental Engineering 141(10): 04015045.

http://dx.doi.org/10.1061/(ASCE)GT.1943-5606.0001343

Indraratna, B.; Nguyen, V. T.; Rujikiatkamjorn, C. 2012. Hydraulic conductivity of saturated granular soils determined using a constriction-based technique, Canadian Geotechnical Journal 49: 607-613. http://dx.doi.org/10.1139/t2012-016

Indraratna, B.; Raut, A. K.; Khabbaz, H. 2007. Constrictionbased retention criterion for granular filter design, Journal of Geotechnical and Geoenvironmental Engineering 133(3): 266-276.

http://dx.doi.org/10.1061/(ASCE)1090-0241(2007)133:3(266)

Indraratna, B.; Vafai, F.; Dilema, E. 1996. An experimental study of the filtration of a lateritic clay slurry by sand filters, in Proceedings of Institution of Civil Engineers. Geotechnical. Engineering 119(2): 75-83. http://dx.doi.org/10.1680/igeng.1996.28167

Israr, J.; Indraratna, B.; Rujikiatkamjorn, C. 2016a. Internal stability of granular filters under static and cyclic loading, Journal of Geotechnical and Geoenvironmental Engineering (unpublished).

Israr, J.; Indraratna, B.; Rujikiatkamjorn, C. 2016b. Laboratory modelling of the seepage induced response of granu- lar soils under static and cyclic conditions, ASTM Geotechnical Testing Journal (unpublished).

Jones, J. A. A. 1981 The nature of soil piping: a review of research. BGRG research monograph 3. Norwich: Geo Books.

Kenney, T. C.; Lau, D. 1985. Internal stability of granular filters, Canadian Geotechnical Journal 22: 215-225. http://dx.doi.org/10.1139/t85-029

Kezdi, A. 1979. Soil physics. Amsterdam, The Netherlands: Elsevier Scientific.

Lafleur, J.; Mlynarek, J.; Rollin, A. 1989. Filtration of broadly graded cohesionless soils, Journal of Geotechnical Engineering 115(12): 1747-1768.

http://dx.doi.org/10.1061/(ASCE)0733-9410(1989)115:12(1747)

Lane, E. W. 1934 Security from under-seepage masonry dams on earth foundations, Transaction of Americal Society of Civil engineers, ASCE 60(4): 929-966.

Locke, M.; Indraratna, B.; Adikari, G. 2001. Time-dependent particle transport through granular filters, Journal of Geotechnical and Geoenvironmental Engineering 127(6): 521-529.

http://dx.doi.org/10.1061/(ASCE)1090-0241(2001)127:6(521)

Nguyen, V. T.; Rujikiatkamjorn, C.; Indraratna, B. 2013. Analytical solutions for filtration process based on constriction size concept, Journal of Geotechnical and Geoenvironmental Engineering 139(7): 1049-1061.

http://dx.doi.org/10.1061/(ASCE)GT.1943-5606.0000848

Richards, K. S.; Reddy, K. R. 2007. Critical appraisal of piping phenomena in earth dams, Bulletin of Engineering Geology and the Environment 66(4): 381-402. http://dx.doi.org/10.1007/s10064-007-0095-0

Sherard, J. L. 1979. Sinkholes in dams of coarse broadly graded soils, in Proceedings of $13^{\text {th }}$ Congress on Large Dams, 1979, New Delhi, 2: 25-35.

Sherard, J.; Dunnigan, L.; Talbot, J. 1984. Basic properties of sand and gravel filters, Journal of Geotechnical Engineering 110(6): 684-700.

http://dx.doi.org/10.1061/(ASCE)0733-9410(1984)110:6(684)

Skempton, A. W.; Brogan, J. M. 1994. Experiments on piping in sandy gravels, Geotechnique 44(3): 449-460. http://dx.doi.org/10.1680/geot.1994.44.3.449

Terzaghi, K. 1922. Failure of dam foundations by piping and means for preventing it, Die Wasserkraft, Zeitschrift fur die gesamte Wasserwirtschaft 24(17): 445-449 (in German).

Terzaghi, K. 1939. Soil mechanics - a new chapter in engineering science, Journal of Institution of Civil Engineers 12(7): 106-141. http://dx.doi.org/10.1680/ijoti.1939.14534

Unites States Army Corps of Engineers (USACE). 1953. Investigation of filter requirements for underdrains. Tech. Memo. No. 3-360. U.S. Waterways Experiment Station, Vicksburg, Miss.

Wan, C. F.; Fell, R. 2008. Assessing the potential of internal instability and suffusion in embankment dams and their foundations, Journal of Geotechnical and Geoenvironmental Engineering 143(3): 401-407.

http://dx.doi.org/10.1061/(ASCE)1090-0241(2008)134:3(401)

Zou, Y.; Chen, Q.; Chen, X.; Cui, P. 2013. Discrete numerical modelling of particle transport in granular filters, Computers and Geotechnics 32(5): 340-357. 